\title{
Evaluation of EBV-LMP1 as prognostic indicator of nasopharyngeal carcinoma in Indonesian patients
}

\author{
A.N.Kurniawan ${ }^{*}$, Ria Kodariah ${ }^{*}$, Meryanne Elisabeth ${ }^{*}$, Averdi Roezin ${ }^{\dagger}$, Soehartati Gondhowiardjo ${ }^{\ddagger}$
}

\begin{abstract}
Abstrak
Empat puluh delapan kasus karsinoma nasofaring yang telah mendapat radioterapi, diperiksa ekspresi EBERnya pada sediaan histologik dengan cara hibridisasi in situ. Didapatkan 69\% kasus yang positif untuk EBER. Sediaan histologik dari kasus yang EBER positif diperiksa ekspresi LMPI- nya dengan cara imunohistokimia dengan hasil 68\% yang positif. Data stadium klinik ke 48 kasus dan respons radiasi dari 32 kasus diperoleh dari rekam medik. Data ketahanan hidup sampai 2 tahun dari 16 pasien diperoleh dengan cara surat menyurat dan hubungan telpon. Secara statistik ditemukan hubungan bermakna antara klasifikasi histopatologik menurut 'Working Formulation' dan respons radiasi. Hubungan bermakna juga ditemukan antara ekspresi LMPl dengan data ketahanan hidup pasien. Hal ini menunjukkan bahwa LMPI yang telah diketahui mempunyai pengaruh terhadap sel limfoid dan epitel, secara klinikopatologik terbukti dapat berfungsi sebagai salah satu indikator prognostik. (Med J Indones 2002; 11: 81-6)
\end{abstract}

\begin{abstract}
Forty eight cases of nasopharyngeal carcinoma patients who had been treated with radiotherapy were analysed for the expression of EBER in the nucleus of the tumor cells by in situ hybridization technique. EBER was expressed in $69 \%$ of the cases. Histologic specimens positive for EBER were then examined for the expression of EBV-LMPI by immunohistochemistry, which showed 68\% positivity. Clinical staging of 48 cases and radiation response of 32 cases were collected. Data of up to 2 years of survival of 16 cases were obtained through postal and phone communication. Statistical analysis showed that the Working Formulation histologic classification of NPC correlated significantly with radiation response. The expression of EBV-LMPI was correlated significantly with the survival of the patients. Thus EBV-LMPI which has been shown to possess influence on lymphoid and epithelial cells, clinicopathologically proved to have a function as prognostic indicator. (Med J Indones 2002; 11: 81-6)
\end{abstract}

Keywords: nasopharyngeal carcinoma, histopathologic types, EBER, EBV.Imp1, survival

Nasopharyngeal carcinoma (NPC) is the $4^{\text {th }}$ most frequent malignancy in Indonesia. ${ }^{\prime}$ NPC has been shown to have a strong relationship with Epstein Barr virus (EBV) infection. Indeed, EBV has been proven to be expressed in all three types of NPC. ${ }^{2}$ Expression of EBV genome in NPC cells could be demonstrated by the occurrence of Epstein Barr-encoded small RNA (EBER) with in situ hybridization technique. The EBV genome contains BNLF-1 gene. One of the products of this gene, the LMP1 protein, has been shown to have oncogenic potential by transforming epithelial cells in

Department of Anatomic Pathology", Ear, Nose and Throat ${ }^{+}$ and Radiology ${ }^{\ddagger}$, Faculty of Medicine, University of Indonesia / Dr Cipto Mangunkusumo National Central General Hospital, Jakarta, Indonesia vitro. ${ }^{3}$ Clinically it was shown that the expression and non-expression of LMP1 in tumor cells showed different tendency of tumor growth and metastasis. ${ }^{4}$

As radiotherapy is the standard treatment for NPC patients, the outcome of this treatment modality is measured eventually as the survival of the patients.

The purpose of this study is to evaluate the role of LMP1 in NPC patients who were treated with radiotherapy compared with their survival until 2 years after treatment.

\section{METHODS}

Forty eight cases of Indonesian NPC patients who came to the Department of Ear, Nose and Throat Dr 
Cipto Mangunkusumo National Central Hospital for biopsy entered this study. The pathologic diagnosis of the biopsy specimen were confirmed at the Department of Anatomic Pathology. These cases were seen in the year 1995, 1996 and 1997. Subsequent to diagnosis, the patients underwent radiotherapy at the Department of Radiology, Division of Radiotherapy, where followup study for a limited time (at least for two months) was done. Afterwards house calls were attempted to record whether the patients were still alive or not.

The histopathologic specimens were analyzed for the expression of EBER, using the standard procedure of in situ hybridization technique. The expression of EBER in histologic specimen was examined right after the completion of each reaction. EBER was registered as 'positive' if purple granules were found in the nucleus of the tumor cells. EBER was considered 'negative' if there were no granules seen in the nucleus.

Specimens from EBER positive cases were then treated by immunohistochemistry using the LMP1 antibody (DAKO). LMP1 was considered 'positive' if the antigen-antibody complex was seen as yellowchocolate granules on the plasma membrane' and intracytoplasmic, while no granules meant 'negative' result.

Radiation response of the cases were assessed within 2 months after completion of radiation, The responses were categorized as complete response (CR), partial response (PR) and no response (NR).

Survival data were collected by stamped retum mailing letters and by phone calls, based upon personal data as written in the hospital medical record.

The histologic diagnosis, clinical staging, radiotherapy data and survival data were collected and tabulated. Statistical analysis using chi-square test, with Yates' correction where necessary, and Mantel-Haenszel chisquare test, was done to look for correlation of the pathologic characteristics and the radiation responses and survival.

Ethical clearance to use the patients' material was obtained.

\section{RESULTS}

The gender distribution was: 35 males and 13 females, which made the ratio of $2.7: 1$. The age distribution of the cases was as follows: the mean age of the patients were 44.5 years, the youngest was 17 years old and the oldest was 70 years old. The histologic types of NPC used in this study is the Working Formulation classification, ${ }^{5,6}$ which divides NPC into 3 types: keratinizing squamous cell carcinoma (KS), type A carcinoma, and type B carcinoma.

Table 1. Histologic types of NPC

\begin{tabular}{lrr}
\hline Histologic types & \# cases & $\%$ \\
\hline Keratinizing Sq. cell carcinoma (KS) & 9 & 18 \\
Type A carcinoma & 28 & 58 \\
Type B carcinoma & 9 & 18 \\
Undifferentiated carcinoma * & 2 & 6 \\
\hline Total & 48 & 100 \\
\hline
\end{tabular}

* Specimen unretrievable for reclassification into the Working Formulation

Clinical staging of the cases as assessed before radiotherapy is seen in Table 2 .

Table 2. Clinical staging (TNM)

\begin{tabular}{cc}
\hline Stage & \# cases \\
\hline I & - \\
II & 1 \\
III & 5 \\
IV & 37 \\
Unknown* & 5 \\
\hline Total & 48 \\
\hline
\end{tabular}

* Data not retrievable from the medical record

Radiation 'response data which were collected from the medical record were available in 32 cases, so further analysis could be done only upon these 32 cases.

The radiation responses in these 32 cases were as follows:

Table 3. Radiation response of NPC cases

\begin{tabular}{lc}
\hline Radiation response & \# cases \\
\hline Complete response (CR) & 12 \\
Partial response (PR) & 18 \\
No response (NR) & 2 \\
\hline Total & 32 \\
\hline
\end{tabular}


The expression of EBER in histologic specimens showed that some of the tumor cells contained abundant and dark granules, while others were less dense and lighter. Both were regarded as positive cases.

Results of the ISH test were recorded as follows :

Table 4. EBER positivity of NPC cases

\begin{tabular}{lll}
\hline POSITIVE & 22 cases & $69 \%$ \\
NEGATIVE & 10 cases & $31 \%$ \\
\hline
\end{tabular}

Immunohistochemical reaction with antibody to LMP1 was done on the 22 cases which showed positive EBER staining.

The result of the 22 cases is shown in Table 5 .

Table 5. LMP1 positivity of EBER -positive NPC cases

\begin{tabular}{lcc}
\hline POSITIVE & 15 cases & $68 \%$ \\
NEGATIVE & 7 cases & $32 \%$ \\
\hline
\end{tabular}

Obtaining the survival data of the patients were successful in only 16 patients. Information was restricted to survival status within 2 years after completion of treatment (Table 6).

Table 6. Survival data of NPC patients

\begin{tabular}{ll}
\hline DEAD & 12 cases \\
ALIVE & 4 cases \\
\hline TOTAL & 16 cases \\
\hline
\end{tabular}

Analysis of EBER and LMP1 expression and radiation response according to histopathologic types are shown in Table 7.
Table 7. EBER, LMP1, radiation response and histologic types

\begin{tabular}{|c|c|c|c|c|}
\hline & \multicolumn{3}{|c|}{ Histopathologic types } & \\
\hline & KS & Type A & Type B & \\
\hline \multicolumn{4}{|l|}{ EBER } & \multirow{6}{*}{$\begin{array}{l}\text { Mantel-Haenszel } \\
\mathrm{X}^{2}=0.0363 \\
\text { (NS) }\end{array}$} \\
\hline positive & 3 & 14 & $5>$ & \\
\hline negative & 3 & 5 & $2\rangle$ & \\
\hline LMP1 & & & $j$ & \\
\hline positive & 2 & 9 & $4\rangle$ & \\
\hline negative & 1 & 5 & $1\rangle$ & \\
\hline \multicolumn{5}{|c|}{ Radiation response } \\
\hline $\mathrm{CR}$ & 1 & 8 & $3>$ & \\
\hline PR & 4 & 11 & $3\rangle$ & $X 2=5.9993$ \\
\hline NR & 1 & 0 & $1\rangle$ & $\mathrm{p}<.025$ \\
\hline
\end{tabular}

From this table it could be seen that there was no significant correlation of the expression of EBER and LMP1 with the histopathologic types of NPC. On the other hand, there was significant correlation of the radiation response with the 3 histologic types of NPC.

Further analysis was done to see the correlation of LMP1 expression with staging of the disease (Table 8).

Table 8. LMP1 expression versus staging

\begin{tabular}{lccc}
\hline & \multicolumn{3}{c}{ Clinical Stage } \\
\cline { 2 - 4 } & II & III & IV \\
\hline LMP1 positive & 0 & 4 & 11 \\
LMP1 negative & 1 & 0 & 6 \\
\hline
\end{tabular}

$\mathrm{X}^{2}$ test for trend $=0.006(\mathrm{NS}) ; \beta=0.06$

There was no significant correlation between the positivity of LMP1 with the staging of the tumor, although the number of cases analysed were small.

The expression of LMP1 was analysed to see its effect on radiation response and survival (Table 9).

Table 9. LMP1 versus outcome of therapy

\begin{tabular}{|c|c|c|c|c|c|c|c|c|}
\hline & \multicolumn{4}{|c|}{ Radiation Response } & \multicolumn{4}{|c|}{ Survival } \\
\hline & $\mathrm{CR}$ & PR & $X^{2}$ & $\mathrm{p}$ & Dead & Alive & $X^{2}$ & $\mathrm{p}$ \\
\hline LMP1 positive & $8^{\circ}$ & 7 & 0 & NS & 4 & 3 & 5.013 & $<.05$ \\
\hline LMP1 negative & 3 & 4 & & & 4 & 0 & & \\
\hline
\end{tabular}


Result of this analysis showed that LMP1 did not correlate well, with radiation response, but was significantly correlated with survival of the patients. Out of 16 cases which had survival data, the number of patients evaluated in this Table was only 11 because the other 5 cases did not have LMP1 examination as they were EBER negative.

\section{DISCUSSION}

This study has several constraints due to the incomplete data retrieved from the medical record (only 32 out of 48 study cases had radiation response data) and the scarcity of follow up data of the patients more than 2 months post radiation. Only $1 / 3$ (16 out of 48) of patients could be traced of their being after completion of treatment. This fact poses a limitation of analysis of the data, although the histopathologic and immunohistochemistry and molecular study could be done completely.

Epstein Barr virus has been linked with several malignancies, such as Burkitt's lymphoma, nasopharyngeal carcinoma, B cell lymphoma, $\mathrm{T}$, cell lymphoma, Hodgkin's disease and gastric carcinoma. ${ }^{7}$ Besides, it is also a causal agent for infectious mononucleosis. Most of the malignancies occur years after viral infection in the cells. In NPC, latent infection of EBV has been detected in vivo as type II latency, expressing EBNA1, LMP1, LMP2A, LMP2B and EBERs. ${ }^{8}$ As EBERs are expressed at high abundance, approximately $10^{7}$ copies per cell in all latently infected cells, EBERs can be consistently detected in NPC specimens by Northern blot and in situ hybridization. The latter technique can be done on paraffin embedded specimen. Thus, the expression of EBER in a histologic specimen denotes the sure existence of EBV genome in the cell. This is the reason why we examined the LMPI expression in all EBER positive cases only. In our series, the positivity of EBER was $68 \%$. This figure is lower than report by Murono et $\mathrm{al}^{9}$ who detected $82 \%$ of EBER in 56 primary NPC cases in Korea. The reason for this difference is unclear, it may be caused by different probe, different technical skill or different strain of EBV. Non expression of the EBER does not necessarily mean that the EBV genome is not present. Takeuchi et al ${ }^{10}$ who detected EBER positive in $75 \%$ of NPC cases, found out that by using PCR method which can detect one copy of EBV DNA per cell, they could detect EBV-DNA in $30 \%$ of the EBER - negative NPC cases. EBER is a non-translated mRNA and the function is so far unclear.

There is no significant correlation between EBER and LMP1 and histologic types of NPC (Table 7). This finding emphasized the fact that EBV has been shown to be found in all three types of NPC. ${ }^{11}$

Result of this study showed that there was statistical significant correlation between the histologic types (the Working Formulation) and the radiation response (Table 7). This finding is in accordance with our previous report, ${ }^{6}$ which showed the percentage difference of radiation responses of the 3 types of NPC. Data from our previous report showed that CR (complete response) can be achieved in $1 / 6(16,6 \%)$ of KS type, and $8 / 19(42,1 \%)$ of type A carcinoma, while type B carcinoma showed a $3 / 7(42,9 \%)$ of $C R$. Thus, this classification could be used as a prognostic indicator of NPC.

LMP1 as a protein product of BNLF1 gene has a molecular weight of $60-66 \mathrm{kD}$. It can be detected in plasma membrane and partly in the cytoplasm as it has 3 domains : intracytoplasmic N-terminus, transmembrane dan intracytoplasmic C-terminus. LMP1 has several functions in vitro, a.o. to immortalize the lymphocytes and several epithelial cells, to upregulate the bcl-2 in lymphocytes and the expression of A20 zinc finger protein in epithelial cells, which may lead to reduced apoptosis. In vivo LMPI has been shown to influence the growth and tendency of metastasis of NPC. Hu et $\mathrm{al}^{4}$ reported that LMP1 positive tumor grew faster and more expansively than LMP1 negative tumor, but had better prognosis. On the other hand, LMPl negative tumor recurred in a higher frequency and showed tendency to form metastasis. Our study confirmed the notion that LMP1 has some influence on the outcome of the patients, as the correlation of LMPI with survival was statistically significant (Table 9). This is true despite the fact of the low number of survival data of our patients, not to mention the other factors that may influence the cause of death of the diseased patients. However, for a short term follow-up, there was no significant correlation of LMP1 with the radiation response (Table 9). To ascertain the influence of LMP1 as an oncogen, ${ }^{12}$ further studies have to be done, such as close monitoring and good recording of the follow-up of the patients after radiation treatment to assess the tumor growth and/or metastasis. This can be done in a good prospective study. Besides, research can be done to 
find a correlation of LMP1 with the proliferation and apoptotic index of tumor. ${ }^{13}$

\section{CONCLUSION}

Analysis of correlation between histopathologic characteristics, radiation response and survival data of Indonesian NPC cases had been done. The result has some limitation due to the small number of retrievable data.

Working Formulation classification of NPC histopathology has significant correlation with radiation response, thus having prognostic importance.

LMP1 did not show significant influence on radiation response, however LMP1 has a role as prognostic factor for survival of NPC.

\section{ACKNOWLEDGMENT}

The authors wish to thank $\mathrm{Li} \mathrm{Fu} \mathrm{Hu}, \mathrm{MD}, \mathrm{PhD}_{\text {, }}$ Karolinska Institute, Stockholm, for the donation of EBER probe and LMP1 antibody to run the pathology tests. Gratitude is also due to National Institute of Health Research and Development, Department of Health, Republic of Indonesia, for research grant for the implementation of the clinical, pathologic and survival study. Guidance and scientific support were accepted from Eijkman Institute for Molecular Biology, Jakarta.

\section{REFERENCES}

1. Cancer in Indonesia 1992. Histopathologic data. Directorate General of Health Services, Department of Health, Republic of Indonesia; Cancer Registry of The Indonesian
Society of Pathologists; Indonesia Cancer Foundation. Jakarta

2. Pagano JS. The Epstein -Barr Virus and Nasopharyngeal Carcinoma. Editorial. Cancer 1994; 74 : 2397-8.

3. Hu LF, Chen $F$, Zheng $X$, Emberg I, Cao SL, Christensson B et al. Clonability and tumorigenicity of human epithelial cells expressing the EBV encoded membrane protein LMP1. Oncogene 1993; 8 : 1575-83.

4. Hu LF, Chen F, Zhen Q-f, Zhang Y-W, Luo Y, Zheng X et al. Differences in the growth pattem and clinical course of EBV-LMP1 expressing and non-expressing nasopharyngeal carcinomas. Eur J Cancer 1995; 31 A : 658-60.

5. Hsu HC, Chen CL, Hsu MW, Lynn TC, Tu SM, Huang SC. Pathology of nasopharyngeal crcinoma. Proposal of a new histologic classification correlated with prognosis. Cancer 1987; 59 : 945-51.

6. Kumiawan AN, Syafril A, Susworo R. Nasopharyngeal carcinoma. An alternative classification as a Working Formulation. Med J Univ Indon 1993; 2 : 37-41.

7. Pagano JS. Epstein-Barr virus: the first human tumor virus and its role in cancer. Proc Assoc Am Physicians 1999; $111: 573-80$.

8. Hu LF. Nasopharyngeal carcinoma and Epstein-Barr virus. Stockholm, Karolinska Institutet,1996. Thesis.

9. Murono S,Yoshizaki T, Park C-S, Furukawa M. Association of Epstein-Barr virus infection with p53 protein accumalion but not bcl-2 protein in nasopharyngeal carcinoma. Histopathol 1999; 34: 432-8.

10. Takeuchi $H$, Kobayashi $R$, Hasegawa $M$, Hirai $K$. Detection of latent Epstein-Barr virus (EBV) DNA in paraffin sections of nasopharyngeal carcinomas expressing no EBV-encoded small RNAs using in situ PCR. Arch Virol 1997; 142: 1743 -56.

11. Vasef MA, Ferlito A, Weiss LM. Nasopharyngeal carcinoma, with emphasis on its relationship to EpsteinBarr virus. Ann Otol Rhino Laryngol 1997; 106 : 348- 56.

12. Nicholson LJ, Hopwood P, Johannessen I, Salisbury JR, Codd J, Thorley Lawson D et al. Epstein-Barr virus latent membrane protein does not inhibit differentiation and induces tumorigenicity of human epithelial cells. Oncogene 1997; 15:275 - 83.

13. Vera Sempere FJ, Burgos JS, Botella MS, Morera C. Immunohistochemical expression of Bcl-2 oncoprotein in EBV-associated nasopharyngeal carcinoma correlated to histological type and survival. Histopathol 1997; 12; 9 18. 


\section{ATTACHMENT TABLE}

\begin{tabular}{|c|c|c|c|c|c|c|c|c|c|c|c|}
\hline NO & SEX & AGE & PA NO. & NPC TYPE & STAGE & RT & DOSE & RR & EBER & LMP1 & SURVIVAL \\
\hline 1 & $\mathrm{~F}$ & 48 & 9502117 & A & 4 & $(+)$ & 66 & PR & $(t)$ & $(+)$ & $?$ \\
\hline 2 & $F$ & 31 & 9592420 & A & 4 & $(+)$ & 66 & PR & $(-)$ & |/IIIIII/I & Dead \\
\hline 3 & $M$ & 58 & 9503490 & $B$ & 4 & $(+)$ & 70 & NR & $(+)$ & $(+)$ & Dead \\
\hline 4 & M & 67 & 9503570 & $B$ & 4 & $(+)$ & 66 & PR & $(+)$ & $(+)$ & Dead \\
\hline 5 & $F$ & 35 & 9504008 & $B$ & 4 & $(+)$ & 66 & PR & $(-)$ & |IIIIIIIII & Dead \\
\hline 6 & $M$ & 39 & 9504538 & KSS & 4 & $(+)$ & 66 & PR & $(+)$ & $(-)$ & ? \\
\hline 7 & $M$ & 41 & 9507326 & A & 4 & $(+)$ & 66 & PR & $(+)$ & $(-)$ & Dead \\
\hline 8 & $\mathrm{M}$ & 38 & 9604602 & A & 4 & $(+)$ & 66 & CR & $(+)$ & $(+)$ & Alive \\
\hline 9 & $M$ & 50 & 9601900 & A & 4 & $(+)$ & 40 & PR & $(-)$ & $\mid / I I I I I I I I$ & Dead \\
\hline 10 & M & 30 & 9602686 & KSS & 4 & $(+)$ & 66 & PR & $(-)$ & $\mid / I I I I I I I I I$ & $?$ \\
\hline 11 & $M$ & 42 & 9602000 & $B$ & 4 & $(+)$ & 40 & $\mathrm{CR}$ & $(-)$ & $\mid / 1 / 1 / 1 / 1$ & Dead \\
\hline 12 & M & 35 & 9602895 & A & 4 & $(+)$ & 66 & PR & $(+)$ & $(+)$ & $?$ \\
\hline 13 & $F$ & 30 & 9603554 & KSS & 4 & $(+)$ & 66 & CR & $(+)$ & $(+)$ & $?$ \\
\hline 14 & $M$ & 63 & 9606207 & A & 4 & $(+)$ & 66 & CR & $(-)$ & $|I|||||||$ & Alive \\
\hline 15 & $F$ & 60 & 9602029 & $B$ & 3 & $(+)$ & 52.8 & CR & $(+)$ & $(+)$ & ? \\
\hline 16 & $M$ & 32 & 9604997 & A & 4 & $(+)$ & 66 & CR & $(+)$ & $(+)$ & Alive \\
\hline 17 & $M$ & 49 & 9504734 & A & 4 & $(+)$ & 66 & $\mathrm{CR}$ & $(+)$ & $(-)$ & ? \\
\hline 18 & $M$ & 50 & 9603972 & $B$ & 4 & $(+)$ & 66 & PR & $(+)$ & $(-)$ & Dead \\
\hline 19 & M & 30 & 9602682 & A & 4 & $(+)$ & 66 & PR & $(-)$ & 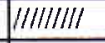 & $?$ \\
\hline 20 & M & 45 & 9606697 & $B$ & 3 & $(+)$ & 66 & CR & $(+)$ & $(+)$ & Dead \\
\hline 21 & M & 51 & 9606418 & A & 4 & $(+)$ & 66 & PR & $(+)$ & $(-)$ & $?$ \\
\hline 22 & M & 36 & 9604434 & KSS & 4 & $(+)$ & 66 & CR & $(+)$ & $(+)$ & Alive \\
\hline 23 & $F$ & 21 & 9603728 & A & 4. & $(+)$ & 66 & PR & $(+)$ & $(+)$ & $?$ \\
\hline 24 & $M$ & 64 & 9602797 & A & 4 & $(+)$ & 52.8 & PR & $(-)$ & $|/| I|I| I \mid I$ & $?$ \\
\hline 25 & $F$ & 55 & 9602927 & A & 4 & $(+)$ & 66 & PR & $(+)$ & $(+)$ & Dead \\
\hline 26 & $F$ & 20 & 9600060 & KSS & 4 & $(+)$ & 66 & NR & $(-)$ & ||$I I|||||| \mid$ & $?$ \\
\hline 27 & M & 43 & 9507250 & A & 3 & $(+)$ & 66 & CR & $(+)$ & $(+)$ & $?$ \\
\hline 28 & $F$ & 23 & 9605237 & A & 3 & $(+)$ & 66 & PR & $(+)$ & $(+)$ & $?$ \\
\hline 29 & M & 65 & 9700248 & A & 4 & $(+)$ & 40 & CR & $(+)$ & $(-)$ & Dead \\
\hline 30 & $F$ & 53 & 9700916 & KSS & 4 & $(+)$ & 66 & PR & $(-)$ & IIIIIIII & $?$ \\
\hline 31 & M & 59 & 9701426 & A & 2 & $(+)$ & 66 & CR & $(+)$ & $(-)$ & Dead \\
\hline 32 & M & 65 & 9701514 & A & 4 & $(+)$ & 60 & PR & $(+)$ & $(+)$ & $?$ \\
\hline 33 & M & 30 & 9504536 & A & 4 & $(-)$ & $?$ & ? & $(-)$ & | $/ 1 \mid \prime \prime \prime \prime \prime$ & ? \\
\hline 34 & M & 17 & 9606702 & A & $?$ & $?$ & ? & $?$ & $(+)$ & $(+)$ & ? \\
\hline 35 & M & 54 & 9604089 & $?$ & $?$ & $?$ & ? & $?$ & $(+)$ & $(+)$ & $?$ \\
\hline 36 & $\mathrm{M}$ & 55 & $96018730 \mathrm{~A} !$ & & $?$ & $?$ & ? & $?$ & $(+)$ & $(-)$ & $?$ \\
\hline 37 & M & 50 & 9605167 & 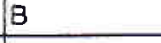 & $?$ & $?$ & ? & $?$ & $(+)$ & $(-)$ & $?$ \\
\hline 38 & M & 62 & 9603393 & KSS & 4 & $?$ & $?$ & $?$ & $(+)$ & $(+)$ & $?$ \\
\hline 39 & $F$ & 43 & 9602843 & A & 4 & $?$ & $?$ & $?$ & $(-)$ & | & $?$ \\
\hline 40 & M & 56 & 9603754 & A & 4 & $?$ & $?$ & $?$ & $(+)$ & $(+)$ & ? \\
\hline 41 & $M$ & 30 & 9604456 & B & 4 & $(+)$ & 30 & $?$ & NS & |IIIIIIII & $?$ \\
\hline 42 & $M$ & 19 & 9502936 & A & 4 & $?$ & $?$ & ? & $(-)$ & $|/||| I I||$ & ? \\
\hline 43 & $F$ & 35 & 9503719 & A & 4 & $(+)$ & 20 & $?$ & $(+)$ & $(-)$ & $?$ \\
\hline 44 & M & 65 & 9502414 & A & 4 & $(+)$ & 50 & PR & NS & $|I I I| I|| \mid$ & $?$ \\
\hline 45 & $M$ & 39 & 9507031 & Undiff * & 4 & ? & $?$ & $?$ & NS & $|/| I|I|||$ & $?$ \\
\hline 46 & $\mathrm{M}$ & 70 & 9603308 & A & 3 & $?$ & $?$ & $?$ & $(+)$ & $(+)$ & $?$ \\
\hline 47 & $F$ & 23 & 9506653 & A & 4 & $(+)$ & 60 & PR & NS & | $/ 1 / 1 / 1 / 1$ & $?$ \\
\hline 48 & $M$ & 63 & 9701929 & KSS & 4 & $(+)$ & 66 & PR & NS & IIIIIIIII & Dead \\
\hline
\end{tabular}

Note: ? = no data available NS = material not sufficient IIIIII = not done
$\mathrm{RT}$ = radiotherapy

$\mathrm{RR}=$ radiation response

* specimen not retrievable for reclassification 